$\xi=-1$

\title{
An Enhancement of Social Capital of fprm Urban Fabric. a Comparison of Three Cities in Indonesia
}

\author{
MS. Barliana ${ }^{1}$,*, Diah Cahyani Permana Sari ${ }^{1}$, Dodit Ardian Pancapana ${ }^{2}$, Beta Paramita ${ }^{1}$,* \\ ${ }^{1}$ Department of Architectural Education, Universitas Pendidikan Indonesia \\ ${ }^{2}$ Regional Cooperation Agency of Bandung \\ *Corresponding author E-mail:
}

\begin{abstract}
The city is a living entity, especially about any urban form; however, the quality of the city would refer to physical qualities. Urban design and spatial planning of the city are good on one hand, and the cultural essence fortified on the other hand. It is important to encourage the strengthening of social capital. Indeed, it is about quality of the city to accommodate quality of life of its citizens. The structure of the physical environment within the city is formed by structural elements (artificial) which cover all elements such as buildings, and various other technical infrastructures connected differently from each other.

This study was carried in Surabaya and Bandung metropolitan city and Surakarta city in Indonesia. This study aims to give a description of urban form quality of each city; the perception of citizens of their own city, then gives the reciprocal of capital, social value, the sense toward urban form and space, which shown in their daily activity.

The results show that Bandung and Surakarta have urban form quality in the "low" level, meanwhile Surabaya has the "high" level. Surabaya with "high" level physical quality has correlation with "high" level of their citizen perception. But somehow, in Bandung and Surakarta this physical quality level has different level perception of their citizen as the image of the city. The perception of Bandung City Image by 43 social communities has mentioned that Bandung has "high" level. This perception also shown in 40 social communities in Surakarta, that its city image has "high" level.
\end{abstract}

Keywords: urban form quality, image of the city, social capital, Indonesian cities.

\section{Introduction}

The physical quality of a city could not be disregarded as it has significant impacts which not only bring the physical comfort but also form a social life of the communities to interact with each other. There are many studies explaining how community quality can be better understood through physical design (Daniel Stokols, 2013; Irene van Kamp, 2003; Tara Smith, 1997). They suggest that physical properties play a more influential role in the enhancement and development of a successful community environment. With regard to this, the physical form of a city is a vital investment.

Social capital, somehow, does not automatically influence the city quality or at least be directly proportional to the urban built environment even though they are correlated. This is in line with Montgomery's (Montgomery, 1998) finding which indicates that the physical-spatial or built-up environment is necessary but in itself insufficient for urbanity. Urbanity means a cultural activity of urban life, where shared values and social networks are included in the scope of social capital. Social capital is very important in social and community life, particularly for providing easy access to information for members of the community, being a medium of power sharing or the distribution of power within the community, developing solidarity, enabling the mobilization of community resources, enabling the achievement of common goals, and forming an attitude of togetherness in community organizations (Lesser, 2000).
Relating to the cultural context of a city and urban life (urban culture), the causes of poverty in social capital are explicable from two sides (Barliana, 2010). The first is the lack of urban planning and design regulations applied in the urban spatial system. The increase of population, including the effect of migration and urbanization, as well as the economic growth, which have encouraged the urban sprawl of big cities, affected the urban form, the physical quality of a city. The second is the unpreparedness or ignorance of the society related to the cultural essence as an understanding of urban beings, which means being ready to negotiate on four aspects of urban life: density, heterogeneity, anonymity and social intensity. The study of social capital in Indonesia itself more related in socio-economy context and aging society (Douglas L. Miller, 2006; Edward Miguel, 2003; Sumarto, 2011). Meanwhile, there are few research about social capital connected to the urban quality.

Surabaya and Bandung become good samples of metropolitan cities, as they are the second and third most populous cities in Indonesia. The various cultures from foreigners and also other migrants different from the main tribes of the cities enrich the characters of the cities. Surakarta, a royal Javanese traditional city, becomes another object of the study. The rapid achievement in urban planning and management makes Surakarta receive several national and international awards. (Howard, 2002; Joebagio, 2013; Tarigan, 2015) 
Thus, Measurement and observation using the numerical rating scale and the semantic differential scale were used to assess the physical quality of the cities. The perceived city quality based on citizens' perceptions then becomes the most important part of the city residents who keep and maintain their cities, representing their sense of belonging to the continuity and dynamism of a city life. Finally, the social capital value of the community gives a description of the living quality of each city.

\section{Literature Review}

\subsection{Measurement of the Quality of Urban Form}

Urban form generally includes a number of physical characteristics such as size, shape, scale, allocation and land use, building type, urban block layout, distribution of green space, as well as non-physical characteristics such as density configurations that form the social environment and social interactions (Jencks, 2010). Thus, when talk about the shape of city, then surely talking about quality in the city to accommodate the quality of life of its citizens The quality of the city at least is determined by three factors (Shirvani, 1985). The first is functional quality in the sense that the quality of city is developed by the spaces between buildings, as well as its connection between buildings in the city systems. The second is visual quality that is related to harmony and architectural appearance in the scale of city, not just a single-unit building (landmark). The third is quality of environment consisting of physical and non-physical qualities that can bring into safety, health and environmental-living comfort. The elements of urban form significantly contribute to quality of the city with respect to four parameters (Greene, 1992), which include: a linkage, continuity, clarity, and equilibrium (balance).

The physical size which accommodated in urban form enhance the perceived quality of city by citizen where their experience during a certain time of their living space. On this basis, a number of measurement parameters can be developed based on the perception of the quality of the city, which is better known as the city's image. Generally, this image is formed by physical or social aspects.

The indicators to measure the city quality refer to physical city dimension. The method to measure is adapted from Kevin Lynch (Lynch, 1982), Jack L. Nassar (Nassar, 1998) and Phillip Kotler (Kottler, 1993). Parameters of urban form quality refer to the concept of physical form criteria developed by Smith, Nelischer, Perkins (Tara Smith, 1997). In general, the physical quality of the city's categories includes aspects of the following physical dimensions:

a. Community: General structure and pattern

b. Urban block: General structure and pattern

c. Buildings: public, government, community, institutional, commercial, industrial, residential

d. Streets: General, byways, main streets, residential streets, laneways

e. Parking: public

f. Pedestrian ways: general, sidewalks, formal trails

g. Open space: General, primary areas, secondary and tertiary areas, semi-public and private areas

h. Vegetation: General

i. Feature areas: Natural resources, views

\subsection{Social Capital in an Urban Form Perspective}

The Quality of the physical form as described previously has an important role in shaping social capital in the community. Good City Form by Lynch has mentioned five categories that refer to theories about the quality of the good city, which includes: vitality (environmental health); sense of place (identity), fit (adjustments, adaptations), access (accessibility for the people, activities, re- sources, places and information) and control (responsibility to the environment). This quality is a reciprocal of social life of its community.

The quality of city will not be automatically built or at least has the same level of alignment with social capital, even though they are correlated. This is in accordance with Montgomery's finding (Montgomery, 1998), that the physical-spatial or built-up environment is a necessary but in itself insufficient condition for urbanity. Without activity, it is impossible to develop urbanity. Urbanity, which also means as a cultural activity of urban life, where urban inhabitants shared values and social networks, also included in the scope of social capital. Developing urbanity means increasing system of social life, starting from the smallest grouping system which is family, extended family, housing community, up to the community at the suburb level, and ends at the community in the city. (Santoso, 2006)

The stronger the sense of place, in the sense that the more a person understands and has a strong sense of attachment to the environment, the higher its sense of community, and vice versa. Thus, the objective quality of physical spatial city is very important to increase the activities of the urban life.

\section{Research Approach and Methodology}

\subsection{Locations and Objects of Study}

As the largest archipelago country in the world, Indonesia has total land of $1,904,569 \mathrm{~km} 2$ containing 17,508 islands; with $237,641,326$ inhabitants, it becomes the 4th most populous country in the world (BPS, 2010). Until today, Indonesia still deals with uneven population distribution. There are 12 cities with high population from the total of 510 cities spreading in the 34 provinces (Figure. 1). These cities have population density of more than $10,000 / \mathrm{km} 2$ and all of them are located in Java Island. Central Jakarta is the most populated region with population density of $17,591 / \mathrm{km} 2$. Meanwhile, the sparsely populated region is Tidore Island, which is only $10 / \mathrm{km} 2$. Java is the main island in Indonesia although it is only $6.87 \%$ of the total land area of Indonesia; $57.25 \%$ of the total population live in this island. The Java Island, which contains six provinces: Banten, DKI Jakarta, West Java, Central Java, D. I Yogyakarta, and East Java, has a different population spread. West Java has the biggest population in Java Island as indicated by figure 2 (Indonesia-BPS, 2013)

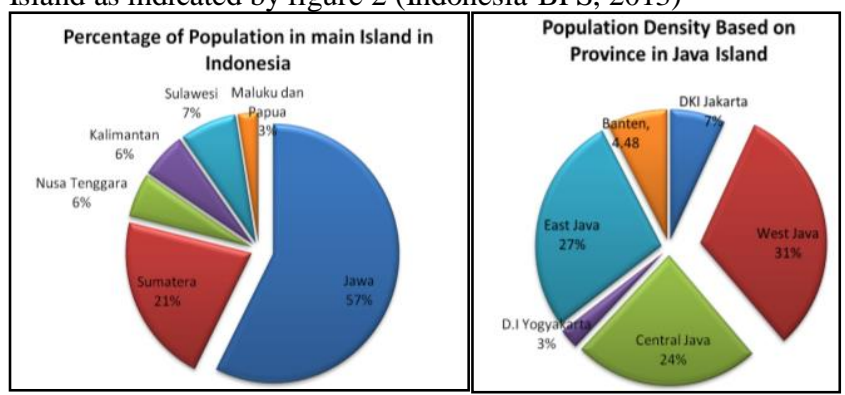

Fig. 2: (a) Percentage of Population in main Island in Indonesia

(b) Population Density Based on Province in Java Island. Source: BPS, 2013

\subsubsection{Surabaya}

Surabaya is the capital city of East Java Province and Indonesia's second largest city after Jakarta. Located in $7^{\circ} 15^{\prime} \mathrm{S}$ and $112^{\circ} 44^{\prime} \mathrm{E}$ with $374.78 \mathrm{~km} 2$ area and 3,114,700 inhabitants make this city have density of $8,310 / \mathrm{km} 2$. Surabaya is also known as the biggest industrial city in Indonesia (Bappeda-Jatim, 2013). Surabaya city and its study area is shown at figure 3 below.

As previously mentioned, the biggest tribe living in Surabaya is Javanese, but there are also other tribes such as Madurese, Sun- 
danese, Batak, Borneo, Balinese and Sulawesi. Foreign ethnics living in Surabaya include Malay, Indian, Arabian and European. This multi-culture enrichs Surabaya's community. Adipura as the highest national award for maintaining and preserving the living environment has been granted to Surabaya from 2006 to 2011 respectively. Since 2009, there are more than 10 awards every year for both national and international scale which have been granted to Surabaya. Surabaya becomes a good model of city which elaborates cooperation between government, privateindustrial sector and the inhabitant. (BPS-Surabaya, 2015)

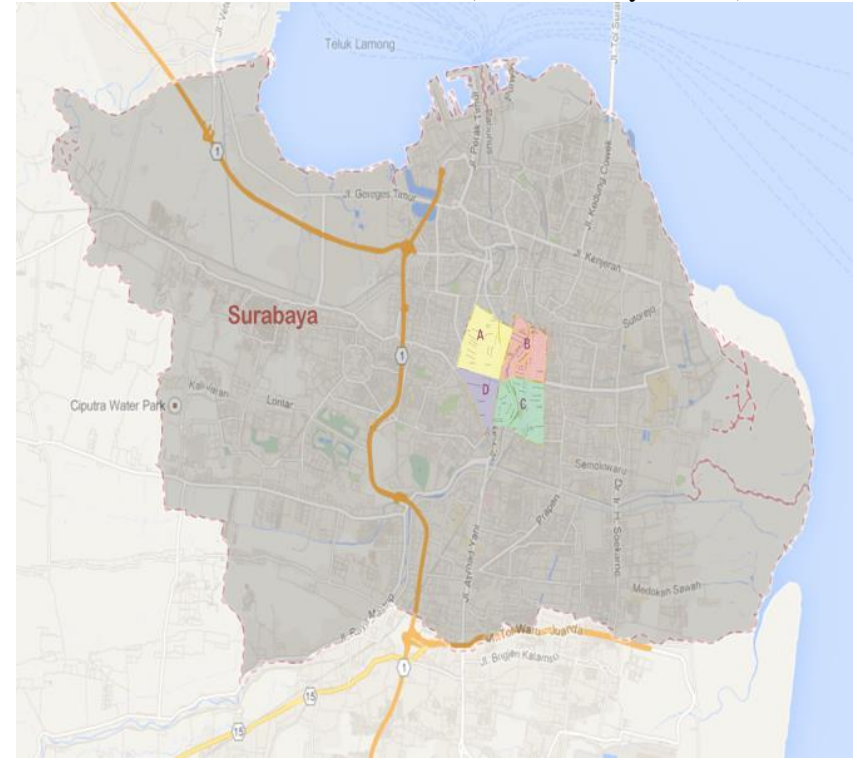

Fig. 3: Surabaya City and Study Area

\subsubsection{Bandung}

Bandung is the capital city of West Java Province; it is also the country's third largest city and second largest metropolitan area in Indonesia after Jakarta. Bandung's geographical location is $6^{\circ} 55^{\prime} \mathrm{S}$ and $107^{\circ} 37^{\prime} \mathrm{E}$ where its population is $2,393,633$ people in an area of $167.67 \mathrm{~km} 2$. Its density is $14,275 / \mathrm{km} 2$. Located approximately $110 \mathrm{~km}$ from Jakarta, the capital city of Indonesia, Bandung is both an international and a domestic tourism destination.

The multi-culture in Bandung is enriched by students who come to study; there are more than 100 higher education institutions in Bandung. The best technology institute in Indonesia, ITB, is located in Bandung. Apart from that, there are also UNPAD and UPI as prestigious national universities.

Located on 768 meters above the sea level, this city has lower temperature compared to other hot-humid cities in Indonesia with average temperature of $18^{\circ} \mathrm{C}$ and maximum temperature of $28^{\circ} \mathrm{C}$ throughout the year. Known as a hilly city with the diversity of flora and remarkable sceneries, Bandung is called as the flower city. Unfortunately, with many intangible and tangible potentials, this city faces some environmental problems, such as squatters as the third biggest problem in Indonesia (Cipta-Karya, 2013), erosive of solid waste landfill which killed 156 people in 2005 and stack of solid waste spreading around the city which is then famous as 'the city of pig" in 2012; it is also recorded as a city with high rain pollution like pH, SO4, NO3 (Bandung_BMKG, 2012). Preliminary studies also found that its urban form and cultural education of urbanity are presumptive in relatively poor quality. (Barliana, 2010). Figure 4 shows the map of Bandung City and study area.

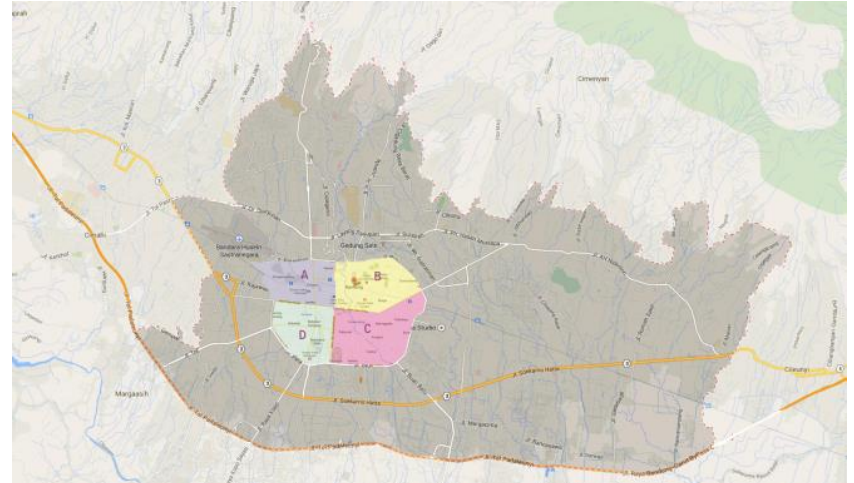

Fig. 4: Bandung City and Study Area

\subsubsection{Surakarta}

Surakarta is known as a traditional city, which has a sultanate among more than hundreds of sultanates in Indonesia. Located in Central Java Province with 520,061 inhabitants in $44 \mathrm{~km} 2$ area, this city has density of 11,811 people $/ \mathrm{km} 2$. Compared to Surabaya and Bandung which have many entrants from other islands or regions, the residents of Surakarta are mostly the original settlers, or just coming from the neighborhood. As the densest city in Central Java Province, it is a special achievement that Surakarta has less slum area compared to other densed cities. Known as the Batik City 1 besides Pekalongan and Yogyakarta, this city is famous with its phenomenal city mayor (2005-2012) who has been elected as the president of Republic Indonesia (2014-2019). He has boosted the city development and transformed it into a city with good physical qualities as well as a good aspect of urbanity of the inhabitants. It is recorded as the cleanest city from air pollution, and granted as a city with the best corruption crackdown by KPK (corruption eradication commission. The study area are shown in figure 5 below.

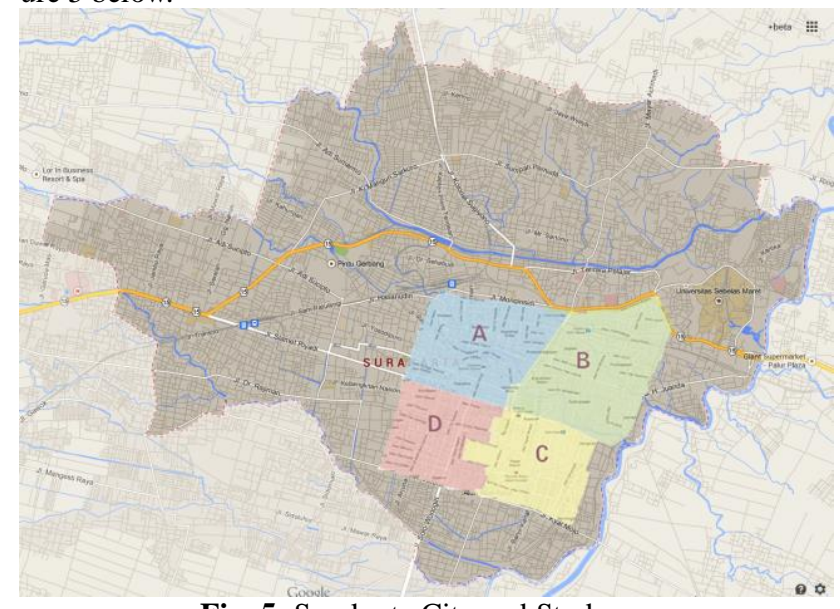

Fig. 5: Surakarta City and Study area.

\subsection{Data Collection}

There are two steps to measure the quality of city. First, the physical quality which is related to the building block, open space, connecting ways also its surface ground coverage, neither by the vegetation, water soil or other artificial layered surface (asphalt, concrete, etc.). This dimension can be observed by the measurements with optional answers covered, performed by experts using the numerical rating scale and semantic differential scale. Measurement, mapping and photographs were compiled with spatial plan and the local regulations are used as an observation tool. At this

\footnotetext{
${ }^{1}$ Batik is traditional pattern in fabric that recognized as an intangible world heritage of humanity.

For this long history, batik becomes one of the important product that is not only in economic benefits to the artisan, but also a strategic buffer to the city income.
} 
stage, one city is selected into four research areas and scored by three experts. Thus, overall, there are 12 group areas. Later, in the data analysis, the number of 12 becomes $\mathrm{N}$ samples.

The second is the quality of the city based on the perception of citizens toward their perceived living space using the questionnaire with Likert scaling. The respondents have been divided into two parts: the specific local community under the same profession, hobby, activities and area; and the common citizens who were selected based on a systematic sample of accidental, i.e. members of the public who experienced the urban space, especially the open space. Data tabulation employed the non-parametric statistics,

Table 2. Descriptive Statistics: The Urban Form Quality of Surabaya

\begin{tabular}{|c|c|c|c|c|c|}
\hline & $\mathrm{N}$ & $\begin{array}{l}\text { Mean } \\
(\mathrm{M})\end{array}$ & $\begin{array}{l}\text { Standard } \\
\text { Devia- } \\
\text { tion (SD) }\end{array}$ & $\begin{array}{c}\text { Ideal } \\
\text { Means } \\
\text { (Mi) }\end{array}$ & Result \\
\hline Public Space & 12 & 70.75 & 7.81 & 55.0 & $\mathrm{VH}$ \\
\hline Urban Block & 12 & 38.5 & 3.29 & 30.0 & $\mathrm{VH}$ \\
\hline Public Facilities & 12 & 55.17 & 5.37 & 47.5 & $\mathrm{H}$ \\
\hline $\begin{array}{l}\text { Government Fa- } \\
\text { cilities }\end{array}$ & 12 & 21.75 & 3.11 & 20.0 & $\mathrm{H}$ \\
\hline Commercial & 12 & 22.67 & 3.14 & 17.5 & $\mathrm{VH}$ \\
\hline Residential & 12 & 44.67 & 3.03 & 37.5 & $\mathrm{H}$ \\
\hline $\begin{array}{l}\text { Urban open space } \\
\text { (central city) }\end{array}$ & 12 & 24.17 & 3.01 & 17.5 & $\mathrm{VH}$ \\
\hline Public Open space & 12 & 15.5 & 1.83 & 15.0 & $\mathrm{M}$ \\
\hline Public Parking area & 12 & 13.58 & 1.38 & 15.0 & $\mathrm{~L}$ \\
\hline Arterial road & 12 & 31.92 & 2.66 & 22.5 & $\mathrm{VH}$ \\
\hline Collector road & 12 & 24.92 & 2.46 & 20.0 & $\mathrm{H}$ \\
\hline Local primary road & 12 & 9.67 & 1.57 & 7.5 & $\mathrm{M}$ \\
\hline $\begin{array}{l}\text { Local secondary } \\
\text { road }\end{array}$ & 12 & 6.83 & 2.69 & 7.5 & M \\
\hline Residential access & 12 & 11.75 & 2.43 & 12.5 & $\mathrm{M}$ \\
\hline Sidewalk & 12 & 26.33 & 3.06 & 22.5 & $\mathrm{H}$ \\
\hline Pathway & 12 & 15.67 & 1.67 & 12.5 & $\mathrm{VH}$ \\
\hline Bike track & 12 & 11.08 & 3.09 & 10.0 & $\mathrm{M}$ \\
\hline Vegetation & 12 & 41.08 & 5.21 & 32.5 & $\mathrm{H}$ \\
\hline TOTAL value & 12 & 486.00 & 45.12 & 0 & $\begin{array}{l}\text { VERY } \\
\text { HIGH } \\
\end{array}$ \\
\hline
\end{tabular}

since the sample was taken purposefully and incidental, which was treated as an ordinal scale.

\subsection{Data Processing - Descriptive Analysis}

Descriptive analysis techniques are used to provide an overview of each of the variables $\mathrm{X}$ and $\mathrm{Y}$ with the display on data frequency, means, mode, and median. The interpretation of the data through the means test is based on the tendency of each variable $(\mathrm{X})$ that is compared with the Ideal Means parameters (Mi) and Standard Deviation (SD). Ideal Means is a fixed parameter which is determined by calculating: $1 / 2 \times$ (minimum + maximum value). (Leavy, 2014; Willis, 2007).
The minimum value is the result of multiplying the value $=1$ by the number of items within the scope of the question and indicator variables for the entire study. The maximum value is the result of multiplying the value $=4$ to the number of items. The means of ideal parameters include the comparative scale of the three object studies (cities). Therefore, the parameters were not referred to every single city of their own, but the mean ideal value remains valid for all cities. Thus, either high or low quality of the city is only able to be valued when compared to other cities. The description of value above is explained as the table 1 below:

Table 1. Descriptive Analysis Value

\begin{tabular}{|l|l|}
\hline Very Low $=\mathrm{X}<\mathrm{Mi}-1.5 \mathrm{SD}$ \\
\hline Low $=\mathrm{Mi}-0.5 \mathrm{SD}>\mathrm{X} \geq \mathrm{Mi}-1.5 \mathrm{SD}$ \\
\hline Medium $=\mathrm{Mi}+0.5 \mathrm{SD}>\mathrm{X} \geq \mathrm{Mi}-0.5 \mathrm{SD}$ \\
\hline High $=\mathrm{Mi}+1.5 \mathrm{SDi}>\mathrm{X} \geq \mathrm{Mi}+0.5 \mathrm{SD}$ \\
\hline Very High $=\mathrm{X} \geq \mathrm{Mi}+1.5 \mathrm{SD}$
\end{tabular}

\section{Result}

\subsection{Urban Fform Quality}

\subsubsection{The Urban Form Quality of Surabaya}

Table 2 provides the result of urban form quality of Surabaya and it is interpreted that the variety of categories was seen on all indicators, but there was no indicator that had very low (VL) quality. Low (L) quality was seen only in the public parking area. Medium (M) qualities were in the public open space, local primary road and local secondary road, residential access also bike track. High (H) quality appeared for public facilities, government facilities, residential, collector roads, sidewalk, and vegetation. Meanwhile Very High (VH) quality was shown at public space, urban block, commercial, urban open space, arterial road and pathway.

\subsubsection{The Urban Form Quality of Bandung}

The indicator of urban form quality in Bandung in total value is low, since $50 \%$ of indicators show medium (M) level, such as: public space, urban block, public facilities, government facilities, residential, urban open space, public open space, arterial road, and local secondary road. The next indicator which was very low (VL) quality includes: public parking area, local primary road, sidewalk, pathway and bike track. Three indicators which are low (L) in quality are: collector road, residential access and vegetation. Meanwhile only one indicator of the high $(\mathrm{H})$ quality category, which is commercial function. This interpretation's result as seen at table 3 . 


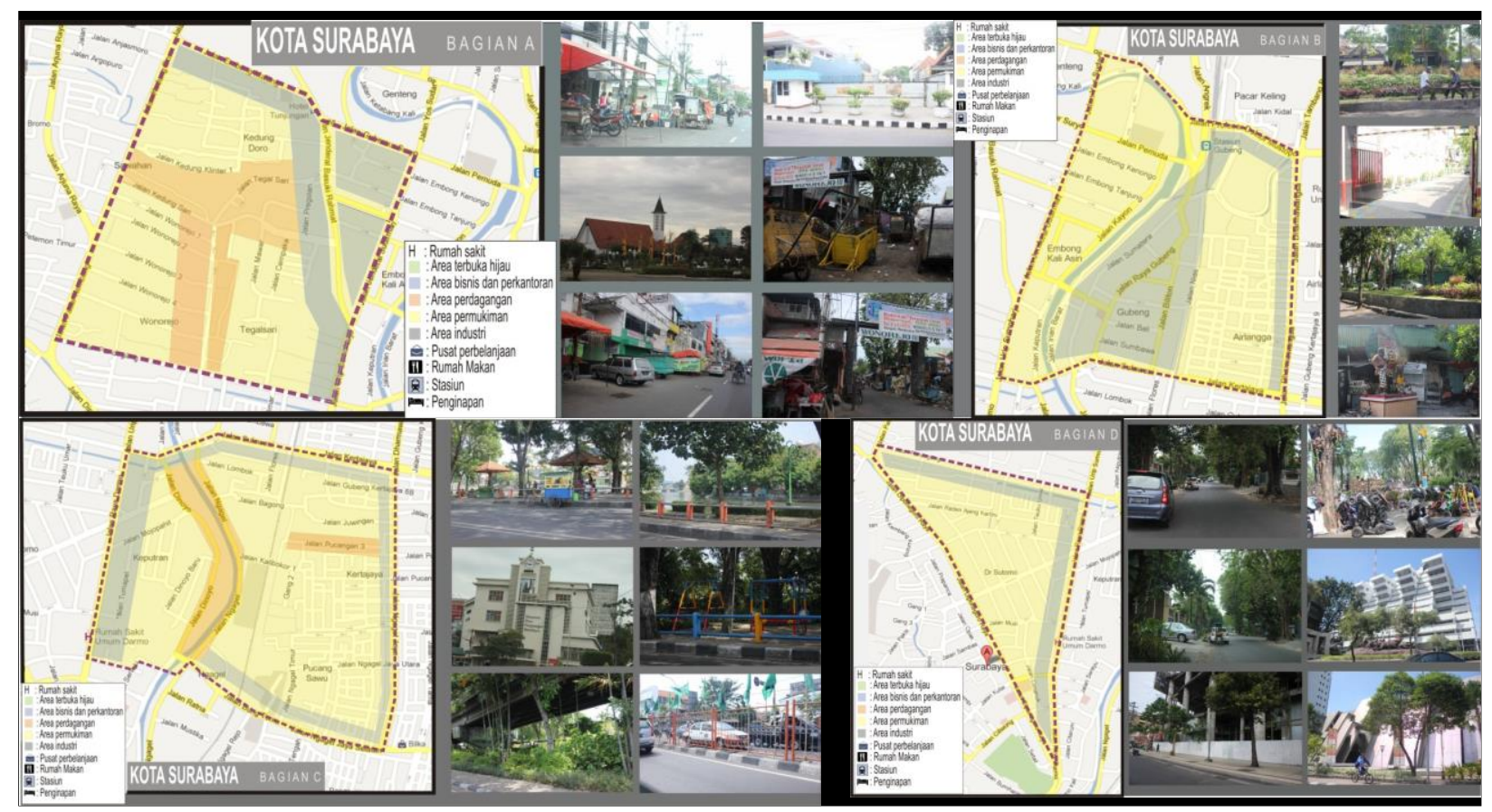

Fig. 6 shows the physical condition of urban form in Surabaya. All the section A,B,C,D of the study area are provide: hospital, green open space, commercial and office area, settlement area, church, train station, and some hotels/hostels

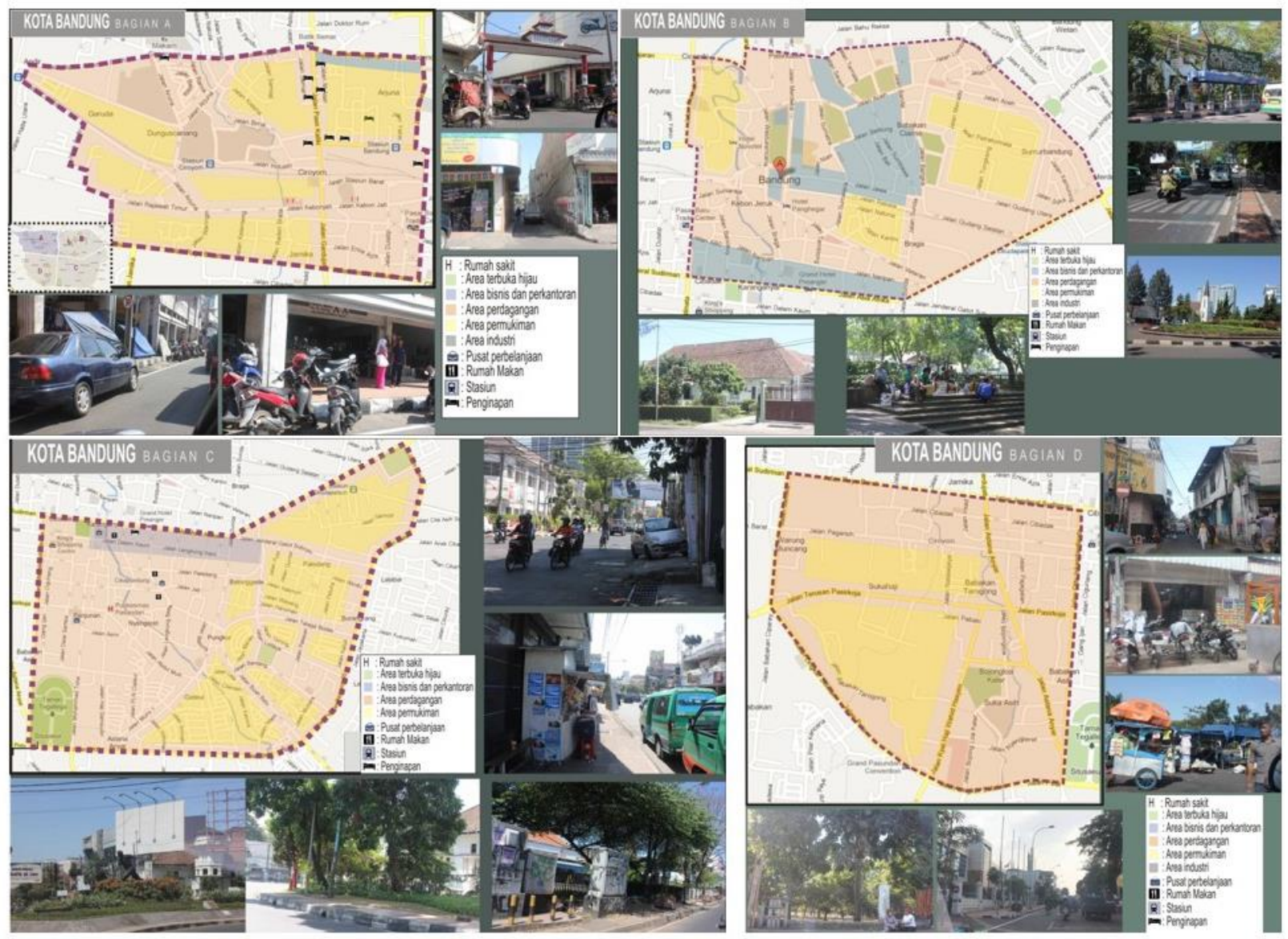

Fig. 7 Describes that the physical condition of urban form in Bandung. There is an imbalance of the existence of public facilities. It is shown that in most of them are not equipped with a proper parking area, public parking area, local primary road, sidewalk, pathway and bike track. The existence of green open space also was not spread all in the city area. 
Table 3: Descriptive Statistics: Quality of Urban Form of Bandung City

\begin{tabular}{|c|c|c|c|c|c|}
\hline Indicators & & $\begin{array}{c}\text { Mean } \\
(\mathrm{M})\end{array}$ & $\begin{array}{l}\text { Standard } \\
\text { Deviation } \\
(\mathrm{SD})\end{array}$ & $\begin{array}{c}\text { Ideal } \\
\text { Means } \\
\text { (Mi) }\end{array}$ & Result \\
\hline Public Space & 12 & 51.75 & 9.34 & 55 & $\mathrm{M}$ \\
\hline Urban Block & 12 & 30.42 & 2.75 & 30 & M \\
\hline Public Facilities & 12 & 48.75 & 4.99 & 47.5 & $\mathrm{M}$ \\
\hline $\begin{array}{l}\text { Government } \\
\text { Facilities }\end{array}$ & 12 & 19.08 & 2.35 & 20 & M \\
\hline Commercial & 12 & 21.42 & 3.20 & 17.5 & $\mathrm{H}$ \\
\hline Residential & 12 & 36.58 & 6.43 & 37.5 & $\mathrm{M}$ \\
\hline $\begin{array}{l}\text { Urban open } \\
\text { space }\end{array}$ & 12 & 17.83 & 5.92 & 17.5 & M \\
\hline $\begin{array}{l}\text { Public Open } \\
\text { space }\end{array}$ & 12 & 12.42 & 4.70 & 15 & M \\
\hline $\begin{array}{l}\text { Public Parking } \\
\text { area }\end{array}$ & 12 & 10.75 & 1.66 & 15 & VL \\
\hline Arterial road & 12 & 21.75 & 2.73 & 22.5 & M \\
\hline Collector road & 12 & 17.17 & 2.72 & 20 & $\mathrm{~L}$ \\
\hline $\begin{array}{l}\text { Local primary } \\
\text { road }\end{array}$ & 12 & 5.83 & 1.19 & 7.5 & VL \\
\hline $\begin{array}{l}\text { Local secondary } \\
\text { road }\end{array}$ & 12 & 7.00 & 1.41 & 7.5 & M \\
\hline $\begin{array}{l}\text { Residential } \\
\text { access }\end{array}$ & 12 & 10.67 & 1.83 & 12.5 & $\mathrm{~L}$ \\
\hline Sidewalk & 12 & 16.42 & 2.19 & 22.5 & $\mathrm{VL}$ \\
\hline Pathway & 12 & 9.75 & 1.48 & 12.5 & VL \\
\hline Bike track & 12 & 6.92 & 1.83 & 10 & $\mathrm{VL}$ \\
\hline Vegetation & 12 & 29.67 & 5.58 & 32.5 & $\mathrm{~L}$ \\
\hline TOTAL value & 12 & 371.67 & 51.18 & 405 & LOW \\
\hline
\end{tabular}

\subsubsection{The Urban Quality of Surakarta}

In general, the urban form quality of the city of Surakarta is in medium (M) category. It is similar condition to Bandung city, $50 \%$ indicator shows the medium $(\mathrm{M})$ category, which are: public space, urban block, public facilities, government facilities residential, collector road, local secondary road, public open space and urban open space. The next indicators appeared the most are in very low (VL) quality, which are: public parking, local primary road, sidewalk, pathway, bike track. Three indicators show low (L) quality, which are arterial road, residential access and vegetation. There is only one indicator showing high $(\mathrm{H})$ quality, which is commercial function. This interpretation's result as seen at table 4.

Table 4. Descriptive Statistics: Quality of Urban Form of Surakarta City

\begin{tabular}{|l|c|l|c|c|c|}
\hline \multicolumn{1}{|c|}{ Indicator } & $\mathrm{N}$ & $\begin{array}{c}\text { Mean } \\
(\mathrm{M})\end{array}$ & $\begin{array}{c}\text { Stand- } \\
\text { ard } \\
\text { Devia- } \\
\text { tion } \\
\text { (SD) }\end{array}$ & $\begin{array}{c}\text { Ideal } \\
\text { Means }\end{array}$ & Result \\
\hline Public Space & 12 & 54.00 & 11.02 & 55.0 & $\mathrm{M}$ \\
\hline Urban Block & 12 & 28.92 & 2.71 & 30.0 & $\mathrm{M}$ \\
\hline $\begin{array}{l}\text { Public Facili- } \\
\text { ties }\end{array}$ & 12 & 41.25 & 4.49 & 47.5 & $\mathrm{M}$ \\
\hline $\begin{array}{l}\text { Government } \\
\text { Facilities }\end{array}$ & 12 & 24.08 & 2.97 & 20.0 & $\mathrm{M}$ \\
\hline Commercial & 12 & 18.75 & 3.14 & 17.5 & $\mathrm{H}$ \\
\hline Residential & 12 & 41.67 & 3.03 & 37.5 & $\mathrm{M}$ \\
\hline $\begin{array}{l}\text { Urban open } \\
\text { space }\end{array}$ & 12 & 15.00 & 3.10 & 17.5 & $\mathrm{M}$ \\
\hline $\begin{array}{l}\text { Public Open } \\
\text { space }\end{array}$ & 12 & 11.75 & 1.86 & 15.0 & $\mathrm{M}$ \\
\hline $\begin{array}{l}\text { Public Parking } \\
\text { area }\end{array}$ & 12 & 9.92 & 1.38 & 15.0 & $\mathrm{VL}$ \\
\hline Arterial road & 12 & 26.83 & 2.66 & 22.5 & $\mathrm{M}$ \\
\hline Collector road & 12 & 20.33 & 2.46 & 20.0 & $\mathrm{~L}$ \\
\hline $\begin{array}{l}\text { Local primary } \\
\text { road }\end{array}$ & 12 & 9.50 & 1.57 & 7.5 & $\mathrm{VL}$ \\
\hline $\begin{array}{l}\text { Local second- } \\
\text { ary road }\end{array}$ & 12 & 5.75 & 0.75 & 7.5 & $\mathrm{M}$ \\
\hline $\begin{array}{l}\text { Residential } \\
\text { access }\end{array}$ & 12 & 10.50 & 2.43 & 12.5 & $\mathrm{~L}$ \\
\hline Sidewalk & 12 & 21.00 & 5.74 & 22.5 & $\mathrm{VL}$ \\
\hline Pathway & 12 & 5.33 & 1.72 & 10.0 & $\mathrm{VL}$ \\
\hline Bike track & 391.08 & 31.39 & 405 & $\mathrm{MEDI-}$ \\
\hline Vegetation & 12 & 3.34 & 12.5 & $\mathrm{UM}$ \\
\hline TOTAL value & 12.5 & 32.5 & $\mathrm{VL}$ \\
\hline
\end{tabular}

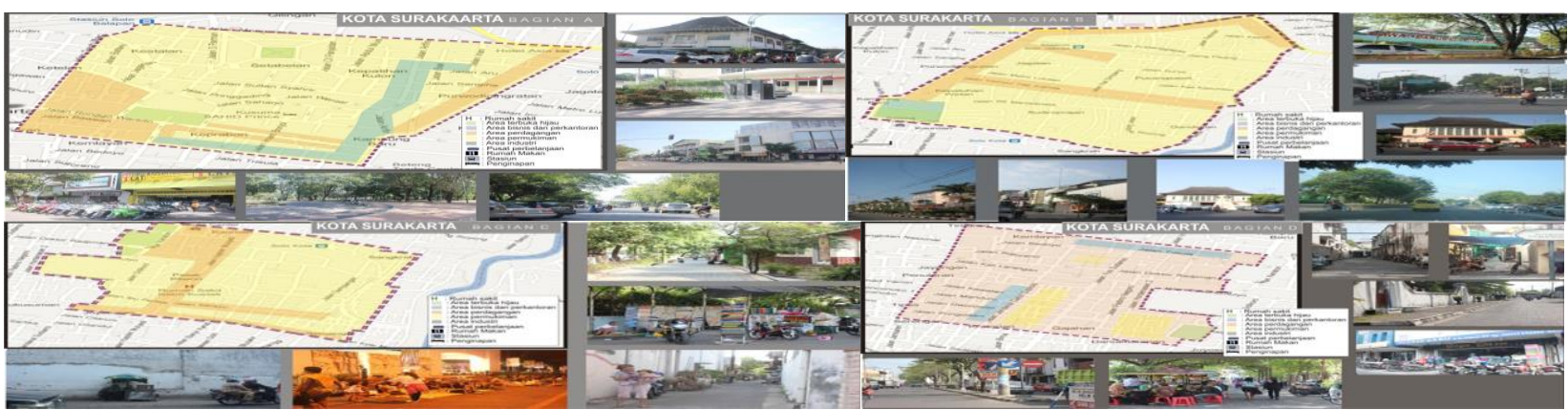

Fig. 8 shows that all the section A,B,C,D of study area there are lack of proper public parking, local primary road, sidewalk, pathway, bike track. It is also shows in every section of study area, between arterial and residential access does not have a perceptible shift.

\subsection{Difference Test Result}

Table 5 shows the difference test result between urban form quality of Surabaya, Bandung and Surakarta. The results are: (1) The null hypothesis is rejected and the research hypothesis is accepted, which means that "there is a significant difference between the urban form quality of the city of Bandung and Surabaya"; (2) The null hypothesis is accepted and the research hypothesis is rejected, which means that "there is no significant difference between the urban form quality of the city of Bandung with Surakarta "; (3) The null hypothesis is rejected and research hypothesis is accepted, which means "there is a significant difference between the urban form quality of the city of Surakarta and Surabaya.

Tabel 5. Difference Test Result for Objective Quality of The City

\begin{tabular}{|c|c|c|c|}
\hline & $\begin{array}{r}\text { Total OQ Su- } \\
\text { rabaya - Total } \\
\text { OQ Bandung }\end{array}$ & $\begin{array}{r}\text { Total OQ Sura- } \\
\text { karta- } \\
\text { Total OQ Ban- } \\
\text { dung }\end{array}$ & $\begin{array}{r}\text { Total OQ } \\
\text { Surakarta- } \\
\text { Total OQ } \\
\text { Surabaya } \\
\end{array}$ \\
\hline $\mathrm{Z}$ & $-3.062^{\mathrm{a}}$ & $-1.020^{\mathrm{a}}$ & $-3.061^{b}$ \\
\hline $\begin{array}{r}\text { Asymp. Sig. } \\
\text { (2-tailed) }\end{array}$ & .002 & .308 & .002 \\
\hline
\end{tabular}

\subsection{The Perception of City Image}


The perception of citizens as city residents has been observed through social community members and common society. Based on the observation, the results of citizens' perception of their home town are shown in Table. 6, 7 and 8. The descriptive analysis techniques are used in the same method with urban form quality. The means of ideal parameters include the comparative scale of the three object studies (cities). Therefore, the parameters were not referred to every single city of their own, but the mean ideal value remains valid for all cities. Thus, either high or low quality of the city is only able to be valued when compared to other cities.

\subsubsection{Perception of City Image of Social Community Mem- ber}

Social community member is a community formed by the similarity of professions and social sensitivity especially regarding environment and the town where they live. There are 3-4 social communities chosen from each city. In Surabaya, there are: Surabaya Tempoe Doeloe Community, Jurnalis Pecinta Lingkungan Community, Kami Arsitek Jengki Community, and Manic Street Walker Community. The communities in Bandung which were observed are Ontel Community, Aleut Community and Sahabat Kota Community. Meanwhile in Surakarta, there are: Sepeda Onthel Community, Solo Kota Kita Community, Kampung Kita Community, and Rebon (Architecture Discussion).

Table 6 Perception of Surabaya City Image by social community member

\begin{tabular}{|l|r|r|r|r|c|}
\hline \multicolumn{1}{|c|}{ Indicator } & \multicolumn{1}{c|}{ N } & \multicolumn{1}{c|}{ Mean } & $\begin{array}{c}\text { Std. } \\
\text { Deviation }\end{array}$ & Mi & Conclusion \\
\hline KS_Total & 42 & 128.71 & 19.97 & 110.00 & $\mathrm{H}$ \\
\hline KS_Livibility & 42 & 27.71 & 4.44 & 25.00 & $\mathrm{H}$ \\
\hline KS_Character & 42 & 31.10 & 4.61 & 25.00 & $\mathrm{H}$ \\
\hline KS_Connection & 42 & 26.05 & 5.46 & 22.50 & $\mathrm{H}$ \\
\hline KS_Mobility & 42 & 16.95 & 3.35 & 15.00 & $\mathrm{H}$ \\
\hline $\begin{array}{l}\text { KS_Personal } \\
\text { Freedom }\end{array}$ & 42 & 17.81 & 2.97 & 15.00 & $\mathrm{H}$ \\
\hline KS_Diversity & 42 & 9.10 & 2.12 & 7.50 & $\mathrm{H}$ \\
\hline $\begin{array}{l}\text { Valid N (list- } \\
\text { wise) }\end{array}$ & 42 & & & & \\
\hline
\end{tabular}

Tabel 6 describes that based on citizen's perception, all the indicators have given the "high" value for City Image of Surabaya. This calculation is based on High $=\mathrm{Mi}+1.5 \mathrm{SDi}>\mathrm{X}$ ? Mi + 0.5 SD. Meanwhile table 7 shows that based on perception of Bandung's citizen, the only indicator that having "medium" value is livability. The other indicators have shown "high" value for city image of Bandung.

Tabel 7: Perception of Bandung City Image by social community member

\begin{tabular}{|l|r|r|r|r|c|}
\hline \multicolumn{1}{|c|}{ Indicator } & N & Mean & $\begin{array}{c}\text { Std. } \\
\text { Deviation }\end{array}$ & Mi & Conclusion \\
\hline KS_Total & 53 & 124.66 & 16.95 & 110.00 & $\mathrm{H}$ \\
\hline KS_Livibility & 53 & 25.19 & 4.34 & 25.00 & $\mathrm{M}$ \\
\hline KS_Character & 53 & 29.96 & 4.29 & 25.00 & $\mathrm{H}$ \\
\hline KS_Connection & 53 & 25.42 & 4.42 & 22.50 & $\mathrm{H}$ \\
\hline KS_Mobility & 53 & 17.81 & 2.82 & 15.00 & $\mathrm{H}$ \\
\hline $\begin{array}{l}\text { KS_Personal } \\
\text { Freedom }\end{array}$ & 53 & 17.47 & 3.25 & 15.00 & $\mathrm{H}$ \\
\hline KS_Diversity & 53 & 8.81 & 1.82 & 7.50 & $\mathrm{H}$ \\
\hline $\begin{array}{l}\text { Valid N (list- } \\
\text { wise) }\end{array}$ & 53 & & & & \\
\hline
\end{tabular}

Table 8 describes that livibility and character are two indicators that having "very high" value for city image of Surakarta based on citizen's perception. Meanwhile, the other indicators such as: connection; mobility; personal freedom; and diversity have the "high" value.

\begin{tabular}{|l|r|r|r|r|c|}
\hline \multicolumn{1}{|c|}{ Indicator } & \multicolumn{1}{c|}{$\mathrm{N}$} & \multicolumn{1}{c|}{ Mean } & $\begin{array}{c}\text { Std. De- } \\
\text { viation }\end{array}$ & \multicolumn{1}{c|}{ Mi } & Conclusion \\
\hline KS_Total & 40 & 137.30 & 21.37 & 110.00 & $\mathrm{H}$ \\
\hline KS_Livibility & 40 & 29.68 & 5.62 & 25.00 & VH \\
\hline KS_Character & 40 & 31.53 & 4.16 & 25.00 & VH \\
\hline KS_Connection & 40 & 28.63 & 5.03 & 22.50 & $\mathrm{H}$ \\
\hline
\end{tabular}

\begin{tabular}{|l|r|r|r|r|c|}
\hline KS_Mobility & 40 & 18.63 & 3.33 & 15.00 & $\mathrm{H}$ \\
\hline $\begin{array}{l}\text { KS_Personal } \\
\text { Freedom }\end{array}$ & 40 & 19.20 & 3.37 & 15.00 & $\mathrm{H}$ \\
\hline KS_Diversity & 40 & 9.65 & 1.87 & 7.50 & $\mathrm{H}$ \\
\hline $\begin{array}{l}\text { Valid N (list- } \\
\text { wise) }\end{array}$ & 40 & & & & \\
\hline
\end{tabular}

\section{Discussion}

It is interesting to further discuss the idea of Surabaya city indicators which are categorized as 'very high' quality. These indicators on public space, urban blocks, commercial buildings, major roads, pedestrian walkways, and downtown open space are discussed below.

Firstly, the public space. It is very reasonable that the objective quality measurement results put the structure and pattern of public space in the city of Surabaya in general in the 'very high' category compared to the city of Bandung and Surakarta. Bandung and Surakarta were only in the 'moderate' category. The observations show that the public spaces in the city center of Surabaya, particularly with regard to open space which can be accessed free of charge by the general public, is very much alive. The community celebrates the existence of a public space, not only on Sunday nights or Sundays and other holidays, but also on the typical days during the week. Although the intensity was lowered, user activities in the public space is still visible. Observations indicate that public spaces in Surabaya, particularly those related to open space are free of charge for the public to access and actively involve the community utilizing them for social purposes.

Secondly, urban blocks with regards to quality core city block are determined by the following aspects: pedestrian space to reach the downtown in Surabaya or urban blocks considered by their pedestrian widths. Pedestrian width and sidewalk are on average more than four yards with constant quality, and not intermittent; so, they provide enough comfort for pedestrians. It means that the pedestrians in the core city of Surabaya are enough to accommodate pedestrian rights, and not solely in favor for the vehicles. Most sidewalks also accommodate the rights of disabled people, providing a marker on floor coverings and ramp. Thus, in general, compared to Bandung and Surakarta, Surabaya downtown gives enough comfort to pedestrians.

Based on the total value of physical form quality and difference test results above (table 5), it appeared that there is no significant difference in objective quality of the city between Bandung and Surakarta. It means that a number of differences in the objective quality of city indicators in the descriptive data can be ignored because in general the qualities of the city of Bandung and Surakarta are objectively equal.

Instead, there is a significant difference between the objective quality of Bandung and Surakarta toward Surabaya. It has actually been indicated before testing any difference hypothesis; as can be seen in the descriptive data, the general objective quality of Surabaya is at the 'very high' category, while Bandung and Surakarta are at the 'low' category. The resume of urban form quality is shown at table 9 .

Table 9. Resume of Urban Form Quality

\begin{tabular}{|c|c|c|c|c|c|}
\hline City & $\mathrm{N}$ & $\begin{array}{c}\text { Mean } \\
(\mathrm{M})\end{array}$ & $\begin{array}{c}\text { Standard } \\
\text { Deviation } \\
(\mathrm{SD})\end{array}$ & $\begin{array}{c}\text { Ideal } \\
\text { Means } \\
(\mathrm{Mi})\end{array}$ & Result \\
\hline Surabaya & 12 & 486.00 & 45.12 & 405.00 & $\mathrm{VH}$ \\
\hline Bandung & 12 & 371.67 & 51.18 & 405.00 & $\mathrm{~L}$ \\
\hline Surakarta & 12 & 391.08 & 31.39 & 405.00 & $\mathrm{M}$ \\
\hline
\end{tabular}

In general, both as perceived by the community members and the general public, the perception of urban quality were "high" in all the cities, such as Surabaya, Bandung, and Surakarta. However, the difference occurs in each of the indicators of city image. Based on the perceptions of members of the community, to the city of Bandung, there are three indicators were high, namely character / 
sense (sense of place, identity), personal freedom / control (responsibility to the environment), and diversity (diversity); indicator category medium / high enough that livability / vitality (environmental health), conection / fit (adjustment, adaptation), mobility / access (accessibility for people, activities, resources, places and information). For Surabaya, high category was seen in all indicators, character / sense (sense of place, identity), personal freedom / control (responsibility to the environment), diversity (diversity), livability / vitality (environmental health), conection / fit (adjustment, adaptation), and mobility / access (accessibility for people, activities, resources, places and information). For Surakarta, there are two categories of indicators including very high, namely livability / vitality (environmental health) and character / sense (sense of place, identity); indicators with high quality, namely personal freedom / control (responsibility to the environment), and diversity (diversity), conection / fit (adjustment, adaptation), and mobility / access (accessibility for people, activities, resources, places and information ).

\section{Conclusion}

Public involvement in the community activity has proven to be an important element to improve the functions of public spaces. The interaction and interrelation between communities are able to instil their sense of belonging toward the city, to respect the other community and to appreciate the city where they live. Thus, the role of public spaces and their activities will strengthen the social capital.

Based on the observation of city image perception from the citizens, it is revealed that urban form quality was not merely determined by the quality of the city; there are important factors such as cultural values which drive the activity in public spaces, and communities to help to improve the public's perception. Therefore, it is required to improve the quality of urban form to the city of Bandung for its livability/vitality, conection/fit and mobility/access. Meanwhile for Surabaya the livability/vitality needs to be improved to enhance the urban form quality

At this stage of observation, the description of urban form quality of Surabaya, Bandung and Surakarta as well as the perception of the citizen toward their city image can be generated. However, this research still need further exploration with various samples needs to be carried out to obtain a model of a more comprehensive arrangement of city and cultural education framework.

\section{Acknowledgement}

Authors would like to thanks to Directorate General of Higher Education of Indonesia Minister of Education (DIKTI) for Strategi Nasional Grant 2011-2012 and Indonesia University of Education (UPI) where all the author work.

\section{References}

[1] Bandung_BMKG. (2012). Bandung Climate Data

[2] Bappeda-Jatim. (2013). Kota Surabaya 2013. Surabaya: Bappeda.

[3] Barliana, M. S. (2010). Arsitektur, Komunutas, dan Modal Sosial. Bandung: Metatekstur.

[4] BPS-Surabaya. (Ed.) (2015).

[5] BPS. (2010). Sensus Penduduk 2010. from http://sp2010.bps.go.id/

[6] Cipta-Karya, P. (2013). Sistem Informasi Kawasan Kumuh Perkotaan. Retrieved 05 April 2015, 2015, from http://ciptakarya.pu.go.id/bangkim/kumuh/main.php?module=home

[7] Daniel Stokols, R. P. L. a. J. H. (2013). Enhancing the resilience of human-environment systems: a social ecological perspective. Ecology and Society, 18(1:7).

[8] Douglas L. Miller, R. S., Suong Lam, Rhonda Rosenberg, Agnes RUPP (2006). Social Capital and Health in Indonesia. World Development, 34(6), 1084-1098.

[9] Edward Miguel, P. G., David I. Levine. (2003). Did Industrialization Destroy Social Capital in Indonesia? Berkeley, California:
CENTER FOR INTERNATIONAL AND DEVELOPMENT ECONOMICS RESEARCH

[10] Greene, S. (1992). Cityshape: Communicating and Evaluation Community Design. APA Journal, 179-185

[11] Howard, W. D. (2002). Surabaya, City of Work: a Socioeconomic History, 1900-2000. Athens: Ohio University Press.

[12] Indonesia-BPS, B. P. S. (2013). Population Density in Indonesian province. 2013, from http://www.bps.go.id/hasil_publikasi/SI_2013/index3.php?pub=Stat istik\%20Indonesia\%202013

Irene van Kamp, e. a. (2003). Urban environmental quality and human well-being: Towards a conceptual framework and demarcation of concepts; a literature study. Landscape and Urban Planning, Elsevier Science Ltd., 65, 5-18.

[14] Jencks, M. a. J., C.A. . (2010). Dimensions of the Sustainable City. . Netherland: Springer.

Joebagio, H. (2013). POLITIK ISLAM DALAM PUSARAN SEJARAH SURAKARTA. Millah, XII(3).

Kottler, P. (1993). Marketing Management: Analysis, Planning, Implementation and Control: Pearson US Imports \& PHIPEs.

[17] Leavy, P. (2014). The Oxford Handbook of Qualitative Research. Oxford: Oxford University Press.

[18] Lesser, E. (Ed.). (2000). Knowledge and social capital: Foundation and application. Boston: Butterworth-Heinemann.

[19] Lynch, K. (1982). The Image of the City. Cambridge: MIT Press.

[20] Montgomery, J. (1998). Making a city: Urbanity, vitality and urban design. Journal of Urban Design, 3, 93-116. doi: $10.1080 / 13574809808724418$

[21] Nassar, J. L. (1998). The evaluate image of the city. New York: Sage Publication.

Santoso, J. (2006). Menyiasati kota tanpa warga. Jakarta: Kepustakaan Populer Gramedia dan Centropolis.

Shirvani, H. (1985). The Urban Design Process. New York: Van Nostrand Reinhold Co.

[24] Sumarto, M. (2011). Welfare Regime, Clientelism, and Social Capital: Evidence from Indonesia. Paper presented at the 8th EASP Conference, Hongkong.

[25] Tara Smith, M. N., Nathan Perkins (1997). Quality of an urban community: a framework for understanding the relationship between quality and physical form. Landscape and Urban Planning, Elsevier Science Ltd., 39, 229-241.

[26] Tarigan, e. a. (2015). Bandung City, Indonesia. Cities, 50, 100-110. [27] Willis, J. W. (2007). Methods of Qualitative Research Foundations of Qualitative Research: Interpretive and Critical Approaches: SAGE. 